\title{
The Effect of "The Book Characters Are Among Us" Activity on the Reading Culture of Students
}

\section{Rahime Ordu}

Turkish Language and Literature Teacher, Haci Ömer Tarman Anatolian High School

We live in an era where knowledge becomes very diverse, expands and change quickly. Reading is the most effective way in order to follow the knowledge, which is accelerated by the democracy and developments of the communication technologies. Therefore, modern societies give special attention to the activities regard to the reading culture.

Nowadays, we are facing a young generation which does not need and care about reading as well as does not know how/why to read a literature writing. This generation prefers a consumption based artificial game world which is served via computer technologies and this kind of artificial places that internet cafes and game centers serve rather than reading and going to libraries.

This study aims to present "Book Characters Are Among Us" activity which makes reading interesting for teenagers by connecting reading with drama and improves their reading, writing and speaking skills. In addition, it evaluates the results of the activity which was held with a group of students.

It was observed that, students started being interested in reading books, doing critical reading to understand and know the characters in the books, obtaining the creative thinking and writing experience and improving their speaking abilities that's to "Books Are Among Us" activity. The activities were intentionally organized in Z Library in order to make students be aware of the facilities and possibilities which were given to their usage. The factors such as comfortable sitting zones, easiness of reaching a book, computer technology, being wide and spacious, usage of the place for book interviews, presentations and drama activities other than book taking and returning are the reasons for students to come to Z Library.

Keywords: Reading culture, Z Library, book characters, dramatization 


\section{Introduction}

eading culture shows the relation between individual and reading activity. This relation was 1 first examined via reading habit. In last years, it was examined with "reading culture" concept (Samur, 2014, p. 181-182).

The reading culture is the summation of interest of a person to literature, duration to reading, following the literature pieces of the era as well as the ones which are old but immortal, choices of writer, work, type of the work, and publisher, gains from reading and usage of the reading knowledge in daily life.

It is an important fact to acquire reading culture as an important obligation of the social life nowadays where developing technology changes and guides our lives with fast spreading knowledge (Sever, 2015, p. 9). Bircan and Tekin (1986, 393) described the the importance of the reading as: “... It is only possible to be a modern, creative, constructive society which has openminded, productive and critical individuals by having people who have reading culture" (Aktaran Aras, 2017, p. 953).

In today's world, the prosperity of a society is directly proportional to its reading culture. The ratio of reader number to population of the society is low in our country. Therefore, we need to accelerate in constructing the reading culture if we want to have a nation which is productive, responsible and modern.

According to Sever (2015), reading culture should be acquired starting from the early ages with a proper education. Sever stressed that this education is not divided into pre-school, primary and secondary ones. Sever developed a comprehensive approach which counts family, social environment, school and teacher. Sever also noted that individuals should have fundamental reading and writing skills with reading habit as well as effective and critical reading skills in order to generalize the reading culture in the society (Sever 2015, pp. 9-29).

Effective and critical reading can be prescribed as observing and recognizing the linguistic composition which forms the text. In addition, it is understanding the meanings of the interaction fields created by the composition and giving meaning to the text. In order to have 
such reading skill, reader has to cut unnecessary information and be a such a reader who is actually a writer, a creator, a teacher and a producer who regenerates him or herself. (Ayyldız, Bozkurt, Canl1; 2006, p. 2).

Effective reader knows sound and signs of the language used in the text. In addition, basic information such as structure, type and syntax of the text is well known. The reader is not limited to direct meanings of these. Instead, he or she questions the text and heads toward new meanings. The reader also questions why the writer of the text tells or doesn't tell a specific part of the text as well as what the text symbolizes in real life and what can be added to the text. The reader uses the effective and critical reading developed with several aspects and his or her own outcomes as a way of living which has some common parts and attitudes with the text.

Being an effective reader and having effective-critical reading ability is cruicial to have reading habit and culture. In other words, being capable of using the experiences acquired after thinking, understanding, questioning and deducing supports learning progress of a person based on the reading. This will encourage the person to read new materials.

It is only possible for the people, who know fundamental reading and writing ability, to have effective-critical reading ability, reading habit and culture with a progress which is well led by family, social neighbor, school and teacher as indicated by Sever (2015). The language and literature education have tremendous contribution to have reading culture. Therefore, they have to be planned in order to support the reading culture of the students (Sever, 2015, pp. 9-29).

In this study, "The Book Characters are Among Us" activity, which can be used by literature teachers, who guides the fundamental language and literature educations inside the school culture, to support reading culture in high school is presented. The same activity, which was held in 2016-2017 education and academic year in Haci Ömer Tarman Anatolian High School, is also examined, extensively.

International Association of School Librarianship https://www.iasl-online.org/ 


\section{Problem Definition}

Today we are faced with a youth who is not interested enough to read, does not feel the need to read, or who does not know why and how to read a literary text. Instead of reading and going to libraries, youngsters prefer playing games in the internet cafes and game centers where an artificial life based on consumption exists. We need ways to make them love reading and gain reading habits.

\section{Method}

Kaya focuses on a number of methods that will lead students to read while referring to the effect of the school on reading cultural. Each of the mentioned methods points out activities that support the reading adventures of him or her and the other students by giving active roles during reading process. (Kaya, 2014, pp. 608-622). In this context, drama by taking the character of the book that the student reads is an activity that will directly affect the reading culture in the school climate, increase the interest in the literature products, raise the reading demand in the students, and carry the reading culture to an upper level in the school tradition. The "Book Characters are Among Us" activity requires the active participation of the students at every stage and leads them to produce and share what they produceç It also presents the ability of reading skills with an active and critical attitude and combines with writing, speaking and listening skills and finally transferring it to drama.

\section{"Book Characters are Among Us" Activity}

This activity is based on the recreation of a selected character from the read book.

The implementation of the activity takes place in three stages:

\section{Decision Making}

1. The selected book is read with a critical perspective.

2. The main and auxiliary characters in the book are identified. 
3. The characters are depicted with their physical and spiritual characteristics.

4. The type and character of the characters and their effects on the event flow are determined.

5. The character to be revived is decided.

\section{Editing Phase}

1. The passages, where the staging technique is used in the book, can be used directly to portray of the chosen character's actions and attitude in the event flow.

2. A monologue can be prepared which reveals the identity of the character by going through the book.

3. A short text in which the character plays an active role can be written.

4. It is possible to animate the character with appropriate improvisations based on the personality of the character without being bound to a written text.

\section{Staging Stage}

1. Memorization is done.

2. Diction work is done.

3. Gest-mimic is studied.

4. Costume, decor is prepared.

5. Stage familiarization.

6. Rehearse.

7. Presentation is made. 


\section{RESULTS}

The target group of the activity, which was held in 2016-2017 education and academic year, are the 9th, 10th and 11th grade students. The target group was primarily informed about active-critical reading and dramatization techniques. In the activity, volunteerism was taken as a basis and a group of thirty people were formed from students who volunteered to read books and play characters. Students are free to choose which book is read and which character is to be selected. In addition to strong works in terms of literary value, weak works were also chosen but the main aim was to focus on reading, loving to read and spending time to read rather than criticize the weak ones. It has been assumed that individuals who have access to reading sensitivity will be directed to qualified works over time. While students were reading books they chose, they gave priority to recognizing and understanding the characters that shaped the event pattern. At the end of the reading session, monologues and dialogue texts for the selected characters were prepared. While these texts were being prepared, it was witnessed that there were also students who wrote their own texts with creative writing technique as well as those who cited the related roman. Dramatization work has been carried out under the guidance of a teacher trained in creative drama.

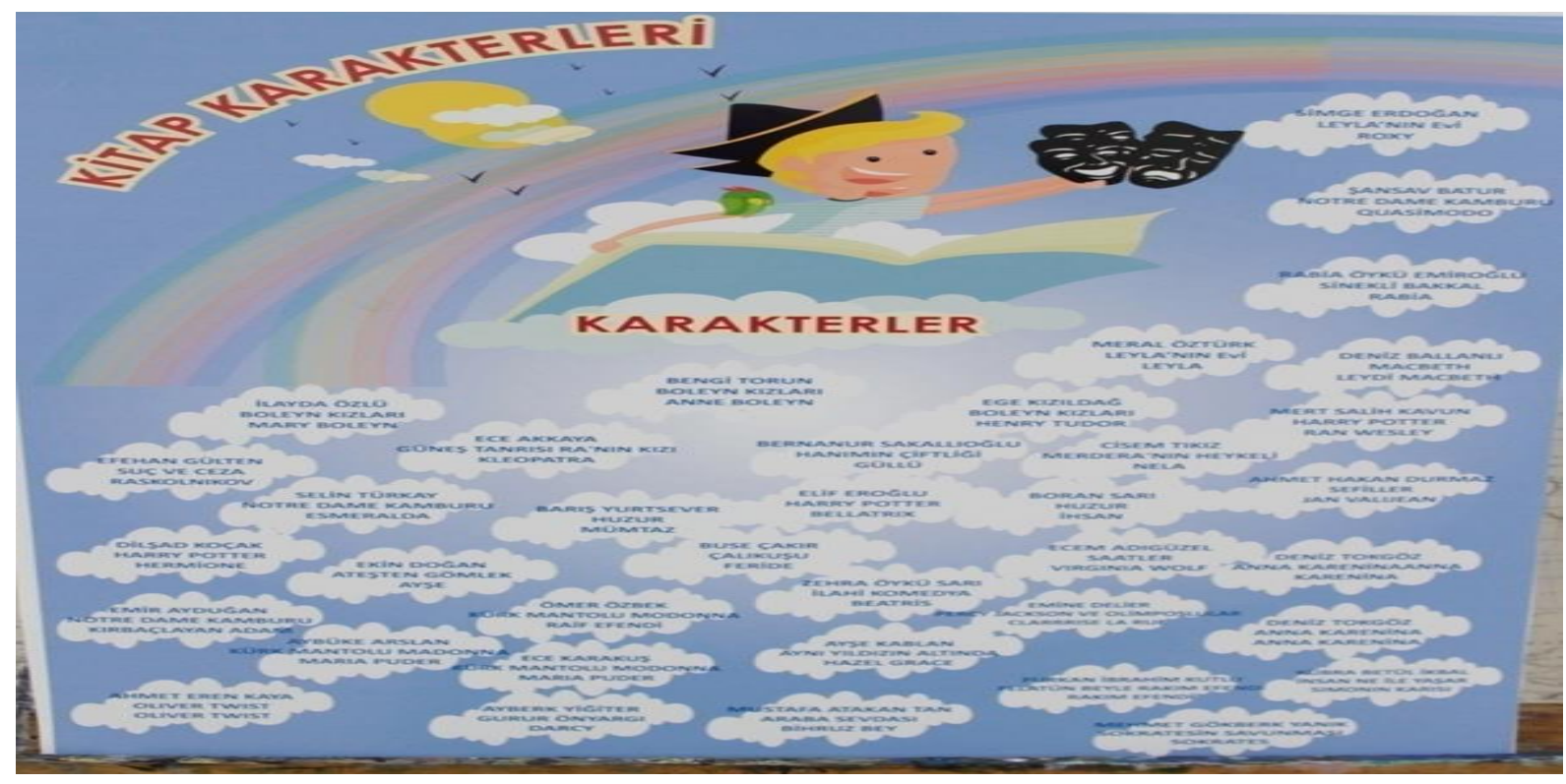

Figure 1: The poster of the activity which was held with thirty students 
The event, which was held with 30 students, was staged three times with different scenes in the Z-library and multi-purpose saloon during the Library Week in our school. The event, which has attracted a great deal of attention from students, continues with the voluntary students within the scope of Z-library activities.

The findings of the three phases of the activity, which were implemented with 30 students, are listed separately below

\section{Decision Making Phase}

1. During the activity, 20 different works from Turkish and World literature. Some of the classics in the World literature such as Divine Comedy, L'Avare, Crime and Punishment, The Hunchback of Notre-Dame, Anna Karanina, The Miserables were also chosen by the students

2. Some students read the same book and headed to different heroes in the book, while others read a book alone and headed to the main hero.

3. When choosing a hero from the works they read, it was seen that the students head to the heroes closer to their own feelings and thoughts they could identify with.

\section{Editing Phase}

1. This phase, which has changed the question from "what is it telling" to "how is narrated", has been a process supporting both critical reading and creative writing.

2. In addition to the directly cited texts, the ones written by the students and by the group work were also used.

Here is a sample text of this phase:

International Association of School Librarianship

https://www.iasl-online.org/ 
"...Take 3 mirrors. Put two of them in a equal distance from yourself. Put the other away from them. Turn your face to the mirrors. Let a light filament come to you after illuminating the mirrors. You will see that image of the mirror which is far away from the others, will appear you in the same amount of shining although it will appear smaller. From now on, you are purified from the wrong knowledge. Divine circles are rotating due to divine actuators. Just like the blacksmith forges the iron. The sky beautified by the several stars takes its beauty from the deep mind which gives it the life. Then it becomes its signature. Just like the brain separates the functions for the organs..."

\section{Dante (Divine Comedy)}

"I am Beatrice. I am one of the three characters in Divine Comedy by Dante. We will first meet with Dante in the heaven. In the heaven which is illuminated by the lights of the knowledge, we will discover all the floors together. I am guiding Dante in this journey."

(The text, which is written by the role player of Beatrice added to the passage

given above)

\section{Staging Stage}

The event was staged three times at the Z-library multipurpose hall in our school during the Library Week. At this stage, with the help of a drama teacher, different scenes were prepared for both library and multi-purpose hall presentations. The presentation was viewed by guests together with our students.

\section{Conclusion and Evaluation}

The interest of the students to read books and to the library has increased. After the lectures, it has been observed that poets and writers as well as their works were discussed, the writings and of the lessons learned during the lessons were chatted, the works in the library have been examined more. In addition, reading lists were prepared and preliminary research on the identity of the main hero was given priority in the novels entering these lists. Participating in the reading activity, acting on the stage, acting the things read and believed, being applauded 
increased the confidence of the students participating in the activity and made important contributions to their language skills. Being based on the volunteerism also affects the work positively. The students are free in the choice of books, heroes, duration of the reading, fictionalization, dressing, accessory and make-up. However, they are only required to justify their choices. This attitude increased the interest to the activity in the school. It has been observed that students who are free in their choices are more sensitive to the school climate, social life, ethical rules and avoid words, attitudes and behaviors which adversely affect the school organization and functioning.

Volunteerism and free choices have increased the awareness of responsibility of students and also positively affected their social development. Students are directed to assessing by following the question of "How is narrated?" rather than "What is narrated?" and they have developed critical reading skills. They acquired creative reading and writing experience during the fictionalization phase. They also noticed through experience that reading and writing skills support each other and that they must read in order to write good quality works. During the event, the school library and the literary products in it became the focus of the students' interest, thus providing an impact on library culture. The use of the library as a study and presentation space by this activity has also increased the interest to the library in the reading culture activities conducted by the Ministry through the Z-library project.

\section{Suggestions}

Character animation events can be applied in different formats. Students can take on the role of a book character and display the skills appropriate for the role throughout the day. In this way, they will be encouraged to continue their own lives with a different point of view and learn to improvise. This application which will carry the book character to everyday life will contribute to the more qualified evaluation of the book that is read. Students have shown interest in proposing a character animation throughout the day with appropriate costumes and accessories within the school, and they have planned a character day event, which will be led by them, 
covering the school personnel, from the teacher to the administrators, the security officer to the workers in the canteen.

\section{References}

1. Aras, G. (2017) Edebiyat ve kültür: Bireysel ve toplumsal gelişmede okuma ve kütüphane alışkanlığı üzerine. Hitit Üniversitesi Sosyal Bilimler Enstitüsü Dergisi, s.2, p.945-968.

2. Ayyıldız, M. ve Bozkurt, Ü. ve Canlı, S. (2006) Okuma kültürü üzerine bir araştırma, Milli Eğitim Dergisi. Erişim: https://dhgm.meb.gov.tr/.../dergiler/Milli_Egitim_Dergisi/169.

3. İnce Samur, Özgül (2014) Türkiye'deki ve Dünya'daki çalışmaların tanıklığında “okuma kültürü’. Hasan Ali Yücel Eğitim Fakültesi Dergisi, s. 22, ss.157-188.

4. Kaya, M. (2014) Okuma kültürü ve çocuk edebiyatı. Türk Dili, CVII, 608-622.

5. Sever, S. (2015) Çocuk edebiyatı ve okuma kültürü. İzmir, Tudem Yayınları. 